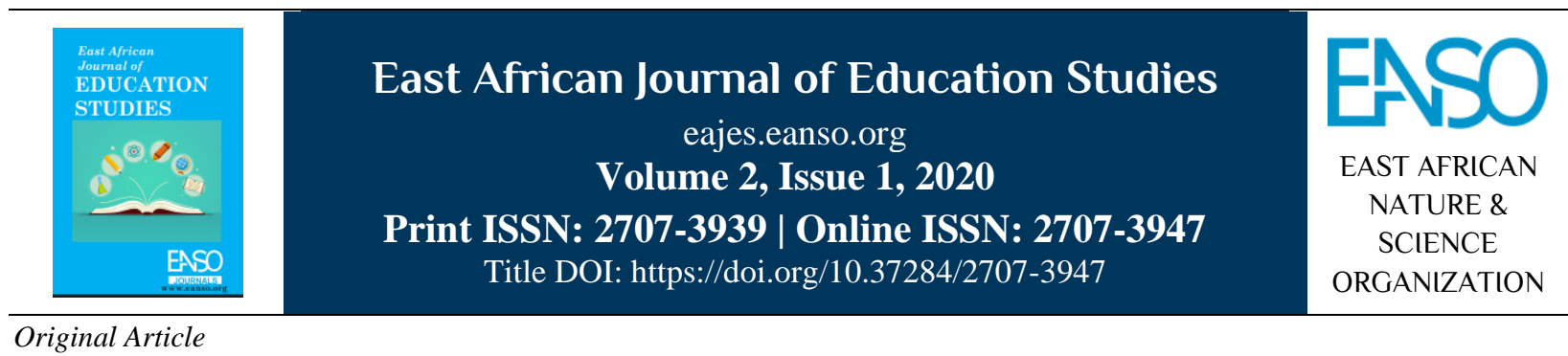

\title{
Suggesting Creoles as the Media of Instruction in Formal Education
}

\author{
Ekiyokere Ekiye ${ }^{1 *}$ \\ ${ }^{1}$ English and Communication Studies, Federal University Otuoke, Nigeria. \\ *Correspondence email: ekiblack2@yahoo.com \\ ORCID: https://orcid.org/0000-0002-2054-174X
}

Article DOI: https://doi.org/10.37284/eajes.2.1.167

\section{Date Published: ABSTRACT}

15 June 2020 Creole and Pidgin languages are spoken by not less than 50 million people around the globe, but literacy is usually acquired in other languages, especially

Keywords: those languages introduced by the former colonial powers. This paper suggests that Pidgin and Creole languages should be elaborated for use as the Pidgin, media of instruction in formal education, particularly in contexts where up to Creole, 85 per cent of the population speak them. Pidgins and creoles researchers have Attitudes, labelled pidgin and creole languages as "developing" and they highlight their Education,

Literacy, Standardisation. capacity to perform the same functions as their developed European lexifiers, English and French. The central argument is that pidgin and creole languages have the potential to express complex realities and function officially in formal education despite the negative attitudes towards them by their speakers. The attitudes towards pidgin and creole languages in education, the part of political and linguistic entities in adopting Nigerian Pidgin and Mauritian Kreol as the medium of teaching literacy in their respective countries are the central issues of focus.

\section{APA CITATION}

Ekiye, E. (2020). Suggesting Creoles as the Media of Instruction in Formal Education. East African Journal of Education Studies, 2(1), 47-58. https://doi.org/10.37284/eajes.2.1.167.

\section{CHICAGO CITATION}

Ekiye, Ekiyokere. 2020. "Suggesting Creoles as the Media of Instruction in Formal Education". East African Journal of Education Studies 2 (1), 47-58. https://doi.org/10.37284/eajes.2.1.167.

\section{HARVARD CITATION}

Ekiye, E. (2020) "Suggesting Creoles as the Media of Instruction in Formal Education", East African Journal of Education Studies, 2(1), pp. 47-58. doi: 10.37284/eajes.2.1.167.

\section{IEEE CITATION}

E. Ekiye, "Suggesting Creoles as the Media of Instruction in Formal Education”, EAJES, vol. 2, no. 1, pp. 47-58, Jun. 2020. 


\section{MLA CITATION}

Ekiye, Ekiyokere. "Suggesting Creoles as the Media of Instruction in Formal Education". East African Journal of Education Studies, Vol. 2, no. 1, Jun. 2020, pp. 47-58, doi:10.37284/eajes.2.1.167.

\section{INTRODUCTION}

"Since the studies of Pidgin and Creole began, there have been calls to promote the use of pidgins and creoles in formal education..." (Siegel, 1993, p. 299). In many multilingual settings like Nigeria, Jamaica, Mauritius, Haiti, etc. where pidgins and creoles are used, they are viewed as degenerate or corrupted forms of the lexifier languages, with claims that they are not suitable for education. Even in situations where language researchers (Migge et al., 2010; Elugbe \& Omamor, 1991; Hall, 1955; 1966) have argued that creoles are valid languages with specific grammatical rules, they have not been accorded any official status for formal education. Instead, the prestigious or standard varieties of the lexifier languages (English, Dutch, Portuguese, and French), usually the languages of the former colonial masters, have remained the primary medium of education.

Siegel (1997) has explained that, like other developed languages, "the grammars of many creoles have been described and other previously unwritten languages such as Bahasa Indonesia have been standardised and elaborated for use in the full range of modern contexts, including education" (p.88). If this is the case, there is no reason why creoles or pidgins should not be adopted as the media of teaching literacy, especially in countries where up to 85 per cent of the population speak these languages. With a focus on Nigerian Pidgin $\left(\mathrm{NigP}^{1}\right)$ and Mauritian Creole, this paper suggests that creoles should be promoted officially as media of instruction in formal education. In line with the foregoing, the paper looked at the background of pidgins and creoles and some of their features, the

\footnotetext{
${ }^{1}$ NigP is used as an abbreviation of Nigerian Pidgin in
} the paper attitudes toward pidgin and creole languages by their speakers, followed by the linguistic situation in Nigeria and Mauritius. It will further examine the arguments for and against the adoption of Mauritian Kreol, and Nigerian Pidgin in education and look at a few countries where, despite the negative attitudes, the creole languages have gone up to the level of official languages as their European counterparts. It will then explore the part of linguistic and political power play in standardising Kreol and NigP in both climes and end with a discussion of the advantages of adopting Kreol and NigP as the medium of instruction. This paper also adopts the terms, expanded pidgin and creole, to mean the same type of vernacular.

\section{A BACKGROUND OF PIDGIN AND CREOLE LANGUAGES}

Pidgin and creole languages emerged from contact situations (especially through slave trading and or massive movement of labourers in the Pacific area) where the individuals who converged at a particular place needed to interact with each other. Since the people in such polylectal communities did not have a common means of communication, they devised ways of interacting by simplifying their existing first languages or by adopting words or phrases they had learnt or tried to learn in their new milieus. As a result of prolonged contact between these individuals, communication conventions evolved and personal variations decreased. From such a simplified mode of communication, a new language called 'pidgin' emerged. Although the lexicon of a pidgin is drawn from the 'lexifier language', its grammar is exclusive and does not share similarities with the dominant language or any 
other contributing language for that matter (Siegel, 2005).

Besides, pidgins are said to have fewer vocabulary, less complex formal structures and lack the "morphological markings for grammatical categories" (Siegel, 1997, p.1). This type of pidgin is not appropriate for education nor as an instrument for teaching literacy as it is restricted to oral use. It is pertinent to note that there are situations where pidgin language use has spread to vast areas, particularly as a language for everyday interaction in multilingual environments. Consequently, the pidgin used in such settings become complex both lexically and grammatically. This form of pidgin is then termed an 'expanded pidgin'. A typical example of an expanded pidgin is the English-based Nigerian pidgin which is currently spoken by seventy- five million speakers (Michealis et al., 2013) and has even been used in writing newspapers, some literary texts and also used for radio and television broadcasts.

From the expanded pidgin, a creole is formed when it becomes the first language or mother tongue for children whose parents (for instance, slaves or plantation labourers) originate from different linguistic communities. A creole, like other developed languages, has complex grammatical rules, rich lexicon, performs a wide range of functions and its use in informal situations is not limited in any way. Examples include the creoles spoken in countries like Haiti, Mauritius, Jamaica, etc. lexified by French and English respectively. According to Siegel (2002), pidgins and creoles are spoken by not less than 76.8 million people who are domiciled in at least 50 countries around the world. While pidgin and creole speakers make up the vast majority of the population in some countries (examples are Nigeria, Jamaica, Guinea-Bissau, Guadeloupe, etc.), in others, speakers from creole and pidgin speaking communities are minorities. An instance is seen in Australia where speakers of the Northern Territory Kriol make up a small proportion of the population or the Creole-speaking immigrants from the Caribbean in the Netherlands.

It is quite interesting to note that in some of these countries like Haiti and Seychelles, creole languages are used in different public domains (example, in political campaigns, the media, vocational coaching, education, etc.). Such developments point to the fact that pidgins and creoles are not only practicable means of communication but, like the other lexifier languages which exist alongside them; they are capable of expressing different social realities or topics. But despite such evident use of creoles in the formal domains, some countries are still reluctant to the idea of adopting them as languages of formal education.

\section{Attitudes towards Creoles in Formal Education}

A language is not just a means of communication; it is also a marker of social identity and group solidarity (Devonish, 1986a; Devonish, 1986b; Siegel, 1997; Sebba, 1997). This explains why some individuals in pidgin and or creole speaking communities show positive attitudes toward pidgin and creole languages; and which is not different from the attitudes exhibited by native speakers of English, French or Portuguese around the world. However, when it comes to the use of pidgins and creoles as languages for teaching literacy, they are immediately subjected to negative attitudes and repression, especially by the individuals who use them.

One of the reasons creole languages have suffered repression can be linked to the circumstances of their formation in history (Shah-Sanghavi, 2017). Most of the regions as Mauritius, where pidgins and creoles are spoken used to be under the control of European powers and even after the Europeans left these colonies, the educated elite pidgin and creole speakers (those who were able to speak the European languages) assumed control over them. Subsequently, the colonial languages (French, 
English, Dutch, etc.) viewed as powerful were adopted for use in administration, education, the media and other public domains. While the European languages gained prestige, pidgins and creoles remained the language of slaves and labourers with low status. Thus, for the current leaders, "the European languages were seen as the key to upward mobility and economic success, pidgins and creoles as languages of slaves or indentured labourers, were associated with repression and powerlessness" (Siegel, 1993, p. 145).

Another reason is that in most countries (for example Jamaica, Trinidad and Tobago, and Guyana) where pidgins and creoles are spoken, they are often compared with their lexifier languages. Siegel (2005) emphasises that when such comparisons are made, educators and speakers alike fail to understand that these European languages have been in existence for a long time, as such, they have well-documented literature while pidgins and creoles do not. Moreover, as far as orthography and standardized grammar are concerned, pidgins and creoles lack standardized grammar and orthography that are acknowledged worldwide even though some newspapers or books written in the languages exist, whereas the European languages have both (dictionaries, grammar books, etc.) and are widely accepted around the globe.

All the same, in other contexts where pidgins and creoles coexist with the standard forms of the European languages, educators and politicians argue that they are not legitimate languages (Siegel, 1997, p. 87). With reference to the attitudes of educators towards creoles in the Caribbean states, Kephart (1992, p. 68) cited in Siegel (1997, p. 87) argue that,

“...you can't express yourself precisely or accurately in Creole, children should be taken away from their creole speaking parents at birth and placed in standard-English speaking homes, because if they spend their whole lives speaking creole, their brain cells will deteriorate."

These beliefs that Creole will ruin the chances of children to perform well in school or deny them opportunities to good jobs and that teaching creoles will be difficult have hindered any large-scale classrooms to use creoles (Sebba, 1997). In fact, creoles are described as corrupted forms of their lexifiers because of their similarity to the colonial languages, especially at the lexical level. In several places, it has and is continually being argued that pidgins and creoles lack grammar and that "the way they are spoken is considered as the result of performance errors rather than language differences" (Siegel, 1993, p145). Edwards (1979, cited in Sebba, 1997, p. 256), in a letter to the Trinidad Guardian, expresses strong disapproval of creoles in education and he comments thus:

"If the language of the barrack yard and the market place is to be the accepted mode of expression in the school-room, in the office and in life generally, all books would be useless, there would be nothing for our children to learn and we could be well close the schools and universities, save the high wages of these experts and set them free to go and plant peas and gather nutmegs where they could give full play to this dialect stuff."

Sebba (1997, p. 235) firmly opposes the standpoint that pidgins and creoles should not be called languages but simply "lingos". Haitian Creole is a typical example of a creole with a long history of contempt, an attitude shared by the French administrators, educators and the general public. However, the situation in Haiti changed in 1964 when François Papa Doc Duvalier modified the constitution of 1918, which allowed the use of Creole for administrative purposes in the country. Furthermore, in 1979, a presidential decree was passed that accorded official status to the Haitian Creole as the medium of teaching literacy and also as a subject of study in schools. With the reorganisation of the Haitian educational system and the creation of Basic Education, the Ministry for 
Education passed a decree in 1983 which mandated that Creole becomes the language of basic education till the sixth year. Finally, in 1987, Creole was made the official language that united all Haitians (Howe, 1993).

Pidgin and creole speaking countries as Haiti and Seychelles have succeeded in overcoming such negative perceptions attached to the use of Creole and Selewa in education. Even in Papua New Guinea, besides the English language, Tok Pisin is the official language and medium of instruction. Mühlhäusler (1997, p. 283) confirm that the use of Tok Pisin in education has advanced beyond the primary level to adult education as observed in para-medical training. Bismala, spoken in Vanuatu also enjoys a similar status officially. Despite the progress made in these countries, it would be difficult, if not nearly impossible for a creole to attain such official recognition (Todd, 1990). As a matter of fact, in Nigeria and Mauritius, the speakers of Nigerian Pidgin and Mauritian Kreole, including administrators and educators, regard their use in education as inadequate. Siegel (2005) observed that such arguments against creoles and pidgins for teaching literacy are hinged upon "issues such as lack of standardisation, fear of interference with the acquisition of the standard form of the European official language, learning of Standard English or French being the ultimate goal of the education system everywhere pidgins and creoles are spoken".

\section{LINGUISTIC PROFILE OF NIGERIA AND MAURITIUS AND THE PLACE OF THEIR RESPECTIVE CREOLE LANGUAGES}

Nigeria and Mauritius are both multilingual and multi-ethnic countries. While Nigeria was colonised by the British, the Republic of Mauritius was occupied by the Dutch, the French and the British at different times. After independence from colonialism (Mauritius gained independence in 1968 and Nigeria became an independent nation in 1960), both countries accorded official status to the colonial languages (French and English in Mauritius and English in Nigeria). Thus, in both contexts, the colonial languages are used exclusively in the domains of public life: the media, government, legal documents, political discussions and also the medium of education. In Mauritius however, only $3 \%$ of the population speak English in informal milieus because Mauritians view it as language acquired in school only (Rajah-Carrim, 2005) while French is used as the medium of wider communication by every ethnic group in the country.

Nigeria is a country which has over 400 languages and 260 ethnic groups. Initially, three major languages (Hausa, Yoruba and Igbo) were chosen as official languages of the country, but they were rejected due to extreme language loyalty amongst the different ethnic group. For a country which was struggling to solidify its independence, a language which would foster nationalism was adopted. Today, English functions as the official language in Nigeria while Hausa, Yoruba and Igbo are taught as school subjects. Besides the colonial languages, creole languages exist alongside the official languages in both countries. These are the Mauritian Creole (also known as Kreol) and the Nigerian Pidgin (also known as Nigerian Creole, Naija) respectively.

In Mauritius, it has been observed that Kreol is spoken by $69 \%$ of the Mauritian population (RajahCarrim, 2005), while NigP is used by more than $75 \%$ of Nigerians. It is also important to state that Kreol is a French-lexified derivation creole that evolved in the 18th century, at the time of the French colonisation. Naija is an English-lexified derivation pidgin that has creolised and evolved as a trade language between the British and the Nigerian people in the 17th century. Although Kreol and NigP are spoken by the majority of the population in both countries, the myth that they are not really languages that can be used in education remains. As such, they have been restricted to informally settings, reserved solely for interaction 
between friends, family or as languages used to communicate with illiterates in the market place in Nigeria and Mauritius.

\section{Attitudes toward Mauritian Kreol and Nigerian Pidgin as Media of Instruction}

The Nigerian and Mauritian positions concerning which language to adopt as the medium of instruction are in some ways, similar to the arguments put forward in other multilingual milieus that are struggling with the issues of language planning. It is observed that in both countries, Nigerians and Mauritians show negative attitudes concerning the implementation of policies, which will accord NigP and Kreol official status as languages of instruction in both countries.

First, in Nigeria and Mauritius, those who favour the retention of English as the language of Education argue that English is an international language and replacing it with a pidgin/creole language would only isolate both countries from the rest of the world. They also argue that as a language of prestige, proficiency in English is the only gateway to economic and educational advancement nationally and internationally. However, such arguments echo the voices of the elite (that is, those who formulate education policies) who view pidgins/creoles as languages of no economic value. There is also the negative attitude associated with the historical formation of NigP and Mauritian Kreol, as contact languages between Europeans and the citizens of Mauritius and Nigeria. Therefore, as in other pidgin/creole speaking countries, it is continually argued in Mauritius and Nigeria that they are not suitable languages for formal domains, not to talk of raising their status as mediums of instruction.

Second, in both Mauritius and Nigeria, there are arguments that NigP and Kreol are broken and nonstandard forms of their lexifiers; therefore, they are not proper languages for formal education. For instance, in Mauritius, it is argued that Kreol has no standard orthography like its French lexifier. As such, it cannot be used as a medium of instruction (Rajah-Carrim, 2007). In Nigeria however, the argument is that NigP lacks uniform orthography. While some scholar advocate for the use of a writing system very much like the Nigerian indigenous languages (Elugbe \& Omamur, 1991), others (Egbokhare, 2001) opine that the orthography of NigP should be based on the English language spelling.

One major concern in 2004 was how the third person pronoun in NigP should be represented. Take this sentence, E/I talk sey e/i go travel tomorrow 'He/She said he will travel tomorrow' as an example. There is no uniformity on whether he/she should be realised as ' $i$ ' or ' $e$ ' in Nigerian Pidgin. It was finally agreed that either could be used. However, this is just one of several unresolved issues regarding the use of NigP. As Deubar and Hinrichs (2007) observe, such unresolved cases imply that users of English-based pidgins and creoles (as well as French-based creoles) are left with their own devices when orthography is concerned.

Another argument against the use of NigP and Kreol as languages of educations is the view that they will affect children's acquisition of the standard variety of lexifier language (English). An instance is seen in the report by The Daily Times on $22^{\text {nd }}$ April 1993 where it was stated that NigP had a negative influence on the acquisition of the English language by children who were first exposed to pidgin before they were introduced to English (cited in Jibril, 1995). It was observed that children realised English structures like 'I don't know' as I no know or 'I am coming' as I dey come. However such transfer from one language to another is not specific to either NigP or Kreol and it has been stated that contrastive analysis could be used as a teaching strategy to eliminate such errors. Those who hold this argument fail to understand that children can be taught to become aware of the 
differences between English and the creole/pidgin languages.

There is also the view that Kreol and NigP cannot express concepts adequately if they are used as media of instruction, as there are no books to sustain literacy. By the same token, the Mauritians and Nigerians who hold this view have refused to acknowledge the fact that there is a growing body of literature at different levels (novels, plays, newspapers, etc.) written in NigP and Kreol. These views, that NigP and Kreol are not suitable languages for education, tend to correspond with the reasons for their exclusion from education in other pidgin and creole speaking countries examined in the previous sections.

Although NigP and Kreol do not enjoy high prestige like their European counterparts, their communicative importance in both multilingual contexts cannot be underestimated. This perhaps informs Eriksen's (1990, p. 14) statement that Kreol is "the unofficial national language" of Mauritius. A similar comment was also made about NigP. Dueber (2005) commented that although NigP had no official policy statement backing it presently, it should be viewed as 'the major lingua franca' in Nigeria. As a result of the communicative roles both languages perform (as solidarity markers amongst the different ethnic groups in both countries), several scholars in Nigeria (Wolf \& Igboanusi, 2006; Igboanusi, 1997) and Mauritius (Eriksen, 1990) have suggested that NigP and Kreol should be assigned an official status (that is, standardised) and promoted as media of instruction in the education systems of both countries.

\section{PROMOTING NIGERIAN PIDGIN AND MAURITIAN KREOL AS OFFICIAL MEDIA OF INSTRUCTION}

The issue of promoting creoles as languages of teaching literacy has been a hotly debated topic in recent times. It is also observed that those who support the use of pidgins and creoles in education focus on the positive effects of teaching literacy through the first language at school. This section discusses arguments for the adoption of Kreol and $\mathrm{NigP}$ as mediums of instruction.

In Mauritius, for instance, linguists such as Virahsawmy (2002) and Tirvassen (1989) emphasize the point that the failure of one in four students who partake in the Certificate of Primary Education (CPE) every year, signals that there are serious issues with the Education System in the country (cited in Rajah-Carrim, 2007, p. 55). The Mauritian editorialist, Ah Nee (2002) comments that the English language was responsible for the high failure rates at both the primary and secondary level, because of its adoption as the sole medium of instruction from the basic years of primary education. It was, therefore, suggested that the languages of instruction needed to change from English, because besides its use in the formal settings, the colonial language was rarely spoken by the Mauritian population. And since Kreol is the first language of majority of the children in primary schools, linguists and educators alike have argued that children will perform in a language they understand. This is the reason why Virahsawmy (2002) asserts that during the basic years of primary education in Mauritius, Kreol should be applied as the medium of teaching literacy and then, children can shift gradually to the English language (cited in Rajah-Carrim, 2007).

Arguments for the adoption of Kreol in education, especially at the primary level, have also been published in several newspaper editorials by groups like Ledikasyon Pu Travayer (LPT). In one of the publications, some members of the LPT group accused the Mauritian Minister of Education of linguistic genocide on monolingual Kreol speaking children. The open letter states:

The State is, in fact, hindering our people in the natural expression of our languages, Bhojpuri and Kreol. It is this that makes the Government responsible, through the schools in particular, for a crime against humanity, the crime of 
linguistic genocide. That is what we are accusing you of, Mr Minister (Collen and Ah Vee, 2003, cited in Rajar-Carrim, 2007, p. 56).

Furthermore, Ah Nee (2002) points out that UNESCO categorically stated that young Mauritians should be taught in their first language. Thus, in according Kreol official status as the medium of instruction, the policymakers in Mauritius would be giving these children their rights to a meaningful education. Such positive arguments for the use of Kreol in education have received the attention of the Mauritian government. In the Mauritian Ministry of Education's Education Reform Act Report for 2008-2014, it was stated that:

In keeping with the multicultural practices in Mauritius, instructions to young learners are given in both English and French, while it is recommended for teachers to start a number of activities in the mother tongue of the learners as scaffolding for the learning of the second languages (Ministry of Education and Human Resources, 2014.)

From the foregoing, it is clear that Kreol is still not placed on the same level as the colonial languages (English and French) in Mauritius. More important is the fact that the Mauritian policymakers (even though there is always the question of how serious they really are) are beginning to acknowledge its use in education. This indicates that changes are beginning to occur in the Mauritian education sector.

Unlike Mauritius, The National Policy of Education (revised in 1981 and 2004) in Nigeria states clearly that, the English language should be taught as a school subject in the basic years of primary school while the children should be taught in any of the three major languages (that is, Hausa, Igbo and Yoruba) in the country. The problem with this policy is that due to extreme ethnic loyalty in the country, Nigerians have refused to accept these languages as medium of instruction in primary school. As aforementioned, Nigeria is made of 260 ethnic groups who speak over 400 languages. How could the Nigerian government pick just three languages for education when only a fraction of the Nigerian population understands the languages chosen? What happens to the other indigenous languages? Are these languages not also suitable for teaching literacy?

Because of questions as those mentioned above, English has continued to dominate the education sector in Nigeria. As the official language of Education, only about $25 \%$ of the Nigerian population speak the English language. What this means is that, besides their respective indigenous languages, $75 \%$ of the Nigerian population communicate in NigP. This is, in fact, the reason why linguists and speakers of NigP have called on the Nigerian government to raise the status of the language. While several scholars like Elugbe and Omamur have stated specifically that NigP should be recognised as the official language of education, some such as Deuber (2005) and Ndolo (1989) have suggested that the Nigerian government should raise its status via a status planning. Others like Wolf and Igboanusi (2006) assert that this language should be used as the sole medium of instruction in the basic years of primary education for pidgin speaking children in the country. Moreover, it is more productive to educate children in a language they can comprehend at the primary level and not in the languages that have been chosen to suit the ambitions of the politically dominant group in the country. Essien (2003) also supports the arguments made by other scholars when he affirms strongly that mother tongue (NigP) should be the medium of instruction in the first three years at the primary level.

Once more, the argument, that NigP is not suitable for formal education because it is not a legitimate language has been refuted by Mafeni and Ofuani (1971) as cited by Ndolo argue that NigP is a legitimate language in its own right. They affirm that, 
Nigerian Pidgin has its own system, with distinct structure, and should not be studied from the point of view of either English or other Nigerian languages; that it is not a haphazard mixture of words, but a language that is meaningfully and systematically used by the great majority of those that constitute its speech community; that it cannot be alternately viewed as a 'simplified form of English' because it is not mutually intelligible. Indeed, it is not immediately understood by visiting Englishspeakers until they have mastered it like any other language - in other words, it is not just another dialect of English and that it now performs more functions than many Nigerian languages that are described as 'full', and whose well-developed status is not questioned.

Moreover, just like English, NigP can be used to write poetry books. This is the case of such works as Pidgin Stew and Sufferhead by Frank AigImoukhuede, Are you ready for African Food by Ben Okri; and plays such as Sozaboy by Ken SaroWiwa and High Life by Wole Soyinka.

In line with the arguments put forward by scholars in Mauritius and Nigeria, this paper supports the view that Kreol and NigP languages should be adopted as media of instruction in both countries especially at the primary level- where majority of the population are monolingual pidgin/creole speakers. The arguments against the use of NigP and Kreol in education examined in the previous section are concentrated on matters regarding the lack of standard orthography and the fear of interference with the acquisition of the standard forms of the colonial language (that is English). These issues are not different from Siegel's (2005) or Sebba (1997)'s observations in other pidgin and creole speaking countries around the world. In my opinion, these concerns in Nigeria and Mauritius can be ameliorated if issues of low status and corpus planning are broached seriously. As aforementioned, Haiti has addressed such issues and today, Creole is both the medium of basic instruction in primary education and a subject taught in Haitian schools. Seychelles is another country where the French-lexified creole, Selewa, has been standardised and used as the official medium of instruction in the first four years of primary school. Although Mauritian Kreol is taught as a school subject in schools, it has not been fully recognised as the official medium of instruction in Mauritius (Rajah-Carrim, 2007).

For NigP and Mauritian Kreol to be adopted as the media of instruction in both countries, issues of status and corpus planning must be solved. According to Siegel (2005, p146), "the aim of status planning is to increase both the status and functions of the pidgin and or creole so that it is used in official contexts alongside the existing official language..." To raise the status of Kreol and NigP via status planning in Mauritius and Nigeria, the government in the different countries need to consciously recognise that they are legitimate languages. Following such recognition, there should be modifications in the roles the languages perform in both contexts; that is, the Kreol and NigP should be used in public or official domains (the media, education and administration) like their European counterparts (English and French). The vast use of NigP and Kreol in such public milieus (instead of restricting their use to informal settings) will brush away the negative attitudes towards these languages in both countries.

It is also a known fact that education is the most significant means through which language policies are implemented (Schneider, 2005). NigP and Kreol should be accorded official status and used as the media of instruction in basic primary education for all pidgin/creole speaking children and other literacy programs in Mauritius and Nigeria. Though strong arguments are backing the use of pidgins/creoles in primary education, it should also be recognised that in situations (like Nigeria and Mauritius) where education in English is highly valued for reasons of social advancement and prestige; education in a first language usually much less, not all of the individuals involved will be 
quickly persuaded of the benefits of training literacy in Kreol and NigP.

To tackle this concern, this study recommends that mother-tongue-based bilingual programs (where the standard forms of the colonial languages are taught as school subjects while Kreol and NigP become the media of instruction) should be introduced in the education systems of both countries. For instance, the instrumental program has been run successfully in San Andrés and Jamaica to introduce their respective creoles as languages for teaching literacy and the standard colonial languages as school subjects (Migge et al., 2010). Since Kreol is already taught as a subject in Mauritian schools, this study recommends that NigP should also be included as a school subject in Nigerian schools. This will help children differentiate between NigP and Standard English and also minimize the fear of parents who feel that instruction in Pidgin will interfere with their acquisition of the English language.

Finally, the problem of standard orthography can be solved through corpus planning. Siegel (2005, p.146) comments that standardisation involves "...choosing a 'standard' variety of the $\mathrm{P} / \mathrm{C}$ to be used for these wider functions and developing a writing system for it (graphization)". Sebba (1997), Adler (1997) and Todd (1990) mention that every language has been standardised based on an already existing model. In spite of the lack of standardisation of Kreol and NigP, a lot of writing in these languages have been recorded. Using those models, language and education practitioners alike should be encouraged to publish books on primary education and this will contribute to establishing standard orthographies for both languages in Mauritius and Nigeria respectively. Works of global significance like the Bible, constitutional documents, etc. should be written using the standard forms of Kreol and NigP. The standardised orthography of Kreol and NigP should be used in other written mediums like newspapers, billboard adverts, and television programs (with subtitles written in the standards form of both languages) which Nigerians and Mauritians are regularly exposed to. This way, the populace in Nigeria and Mauritius will also be exposed to the written standard of both languages.

\section{CONCLUSION}

This paper dealt with the use of creole languages as media of instruction in creole speaking countries, with particular focus on Nigeria and Mauritius. Even though Kreol and NigP are spoken by the majority of the population in Nigeria and Mauritius, they are excluded from the education system in both contexts. Close examinations of the arguments against the adoption of Nigerian Pidgin and Mauritian Kreol for teaching literacy show that such arguments are related to issues like the lack of standard orthography and the fear of interference in the acquisition of standard forms of the lexifier languages (that is, French and English).

This paper suggests that creoles should be adopted as the media of instruction in Nigeria and Mauritius, especially at the primary level of education where up to 80 per cent of the population, especially children, are monolingual creole or pidgin speakers. Adopting Nigerian pidgin and Kreol, as mediums for teaching literacy in Mauritius and Nigeria, will ease the monolingual Kreol and NigP children's adjustment into the school environment. This is because children, if supported in their formative years, find it easy to learn a foreign or new language and they also retain new ideas in their first language.

For this to be realised, however, there needs to be political will to effect positive changes like the introduction of education reforms that enable the regular use of NigP and Kreol, as well other creole languages for that matter, in public domains (that is, in newspapers, on the radio, television, for intellectual and literary as well as political endeavours). With changes in the status, attitudes toward NigP and Mauritian Kreol as languages of 
teaching literacy in formal education will become more open. Consequently, the issue of interference will gradually die out because the parents of creole and pidgin speaking children in Nigeria and Mauritius will also begin to understand that, adopting NigP and Kreol as the languages of instruction will equip their children with the necessary skills, which may be positively transferred to the standard forms of the lexifier languages (that's English and French) in both contexts.

\section{REFERENCES}

Ah Nee, G. (2002). Kifer Kreol. Le Mauricien, 14.

Devonish, H. (1986a). Language and Liberation: Creole Language Politics in the Caribbean. London: Karia Press.

Devonish, H. (1986b). The Decay of Neo-colonial Official Language Policies: The Case of the English lexicon Creoles of the Commonwealth Caribbean. In: Görlach and Holm (eds.). Focus on the Caribbean. Amsterdam: John Benjamins.

Deuber, D. (2005). Nigerian Pidgin in Lagos: Language contact, variation and change in an African urban setting. London: Battlebridge Publications.

Deuber, D. \& Hinrichs, L. (2007). Dynamics of orthographic standardization in Jamaican Creole and Nigeria Pidgin. World Englishes, 26 (1), 22-47.

Elugbe, B. and Omamor, A. (1991). Nigerian Pidgin: Background and prospects. Ibadan: Heinemann Educational Books.

Essien, O. E. (2003). The minority question revisited. In: Ndimele, O. (ed.) Four Decades in the Study of Languages and Linguistics in Nigeria: A Festschrift for Kay Williamson (p.27-37). Aba: National Institute for Nigerian Languages.
Ehrhart, S. et al. (2006). Pidgins and Creoles between endangerment and empowerment: a dynamic view of empowerment in the growth and the decline of contact languages, especially in the Pacific. In: Martin, P., Fishman, A. and Aertelaer, J. (eds.) Along the Routes to Power: Explorations of Empowerment through Language. Berlin: Mouton de Gruyter, 129-55.

Egbokhare, F. O. (2001). The Nigerian linguistic ecology and the changing profiles of Nigerian Pidgin. In: Igboanusi, H. (ed.) Language attitude and language conflict in West Africa (p. 105-24). Ibadan: Enicrownfit.

Eriksen, T. H. (1990). Linguistic diversity and the quest for national identity: The case of Mauritius. Ethnic and Racial Studies, 13 (1), 124.

Hall, R. A. Jr. (1955). Hands of Pidgin English. Sidney: Pacific Publications.

Hall, R. A. Jr. (1966). Pidgin and Creole Languages. Ithaca and London: Cornell University Press.

Howe, K. (1993). Haitian Creole as the official language in Education and the Media. In: Bryn, F. and Holm, J. (eds.) Atlantic Meets Pacific: A Global View of Pidginization and Creolization (p. 291-297), Amsterdam: John Benjamins.

Igboanusi, H. (1997). Language and Nationalism: The future of English in Nigeria's Language Policies. Journal of Social and Cultural Studies, 1(2), 21-34.

Jibril, M. (1995). The elaboration of the functions of Nigerian Pidgin. In: Bamgbose, A., Banjo, A. and Thomas, A. (eds.) New Englishes: A West African perspective (p. 232-47), Ibadan: Mosuro.

Michaelis, S. M. et al (Eds.). (2013). The survey of Pidgin and Creole languages (Vol. 1). Oxford University Press. 
Ministry of Education and Human Resources. (2014). Education reforms in action 20082014. Retrieved on December 20, 2015, from the Ministry of Education and Human Resources from

http://ministryeducation.govmu.org/English// DOCUMENTS/EDUCATION\%20REORT\%2 0IN\%20ACTION.

Migge, B., Léglise, I., \& Bartens, A. (2010). Creoles in education. A discussion of pertinent issues. In: Migge, B., Léglise, I., \& Bartens, A. (eds), Creoles in Education: a Critical Assessment and Comparison of Existing Projects, (p. 1-30): John Benjamins

Mühlhäusler, P. (1997). Pidgins and Creole Linguistics: Expanded and Revised Edition. London: Basil Blackwell.

Ndolo, I. S. (1989). The case for promoting the Nigerian Pidgin language. The Journal of Modern African Studies, 27(4), 679-684.

Shah-Sanghavi, P. K. (2017). Should creoles be made official languages and/or media of instruction in countries where they are the first language of the majority of the population? IOSR Journal of Humanities and Social Science (IOSR-JHSS), 22 (10), 19-25.

Rajah-Carrim, A. (2005). Language use and attitudes in Mauritius based on 2000 population census. Journal of Multilingual and Multicultural Development, 28 (4), 317-332.

Rajah-Carrim, A. (2007). Mauritian Creole and language attitudes in the Education system of multiethnic and multilingual Mauritius. Journal of Multilingual and Multicultural Development, 28 (1), 51-71.

Sebba, M. (1997). Contact Languages: Pidgins and Creoles. New York: Palgrave.

Siegel, J. (1993). Pidgins and Creoles in Education in Australia and the Southwest Pacific. In:
Bryn, F. and Holm, J. (eds.) Atlantic Meets Pacific: A global view of Pidginization and Creolization (p.299-308). Amsterdam: John Benjamins.

Siegel, J. (1997). Using a Pidgin language in formal Education: Help or hindrance? Applied Linguistics, 18 (1), 86-100.

Siegel, J. (2002). Pidgins and Creoles. In: Kaplan, R. (ed.) Handbook of Applied Linguistics. New York: Oxford University Press, (p.335-351).

Siegel, J. (2005). Literacy in Pidgin and Creole Languages. Current Issues in Language Planning, 6 (2), 146-163.

Schneider, B. (2005). Linguistic Human Rights and Migrant Languages. English and American Studies in German, 2005(2005).

Taiwo, R. (2009). The functions of English in Nigeria from earliest times to the present day. English Today 25 (2), 3-9.

Todd, L. (1990). Pidgins and Creoles. London: Routledge.

Virahsawmy, D. (2002). Literesi an Morisien, Rose-Hill: Linprimri HS3.

Wolf, H. and Igboanusi, H. (2006). Empowerment through English - a realistic view of the educational promotion of English in postcolonial contexts: the example of Nigeria. In: Martin, P., Fishman, J. and Neff, J. (eds.) Along the routes to power: Explorations of empowerment through language (p. 333-356). Berlin: Mouton de Gruyter. 